III.

NOTICES OF SCULP'TURED FRAGMENTS, FORMERLY IN THE EPISCOPAJ

PALACE, GLASGOW; ALSO, NOTICE OF A SARCOPHAGUS FOUND WITHIN

TIE CHOIR OF THE CATHEDRAL, SUPPOSED TO HAVE CONTAINED

THE REMAINS OF ARCHBISHOP DUNBAR. BY J. C. ROGER, EsQ., F.S.A.

Scot.

Two sculptured stones, of which a slretch is exhibited in Plate VII., are inserted in the wall of an old tenement at the foot of the High Street of Glasgow. These fragments, which constitute the only remains of the Gate-house to the Episcopal Palace of Glasgow, measure together seven feet in length, and about three and $a$-half feet in breadth across the lower stone, the upper portion of which contains the insignia of Archbishop Dunbar. These are on a heater-shaped shield; three cushions within the doubletressure of Scotland, ${ }^{1}$ being the arms of Randolph, Earl of Moray, assumed by the family of Dunbar subsequent to the marriage of the son of the Earl of March to the daughter of the former. Behind the arms

I Stuart, the author of "Views and Notices of Glasgow in former Times," in noticing this coat, speaks of a mullet as occupying the centre space between the three cusbions, a fact which there is no reason to doubt, the place where this figure has scaled off being readily distinguishable. 
is the crosier, or archiepiscopal cross, the former term being now used to denote the pastoral staff, with which, in verbal description, it is sometimes confounded. Underneath the shield, curved in the line of its base, occurs the salmon with the ring, the badge of the Episcopal See. Gavin Dunbar was son of Sir John Dunbar of Mochrum, ${ }^{2}$ brother of Archibald Dunbar, designed of Baldoon, and nephew of Gavin Dunbar, Bishop of Aberdeen. ${ }^{3}$ His grandfather, Sir Alexander Dunbar of Westfield, was eldest son of the Earl of Moray; but, through the superior influence of the house of Douglas, was declared illegitimate, on account, it is alleged, of his mother having been within the degree of consanguinity proseribed by the Canon Law. ${ }^{4}$ Dunbar, who received his edueation at the University of Glasgow, ${ }^{5}$ was preceptor to James V. ${ }^{6}$ In 1518 he was promoted to the Deanery of Moray, ${ }^{7}$ was made Prior of Whithorn in $1519,{ }^{8}$ elevated to the Archiepiscopal See of Glasgow in $1524,{ }^{9}$ and appointed Chancellor of the Kingdom in $1528,{ }^{10}$ and one of the Lords of the Regency in 1536. He died in $1547,{ }^{11}$ and his remains were deposited in a tomb erected by himself, "within the chancel of his eathedral."12 The nether shield, which in shape resembles the former, bears a chevron ehequé between two martlets-in-chief respecting, and one in base, a rose or cinquefoil occupying the middle chief point, being the arms of James Houston, Sub-dean of the Chapter, whose seal, deseribed by Mr H. Laing, at p. 77 of his " $\mathrm{Ca}$ talogue of Ancient Scottish Seals," is exhibited in the annexed drawing. ${ }^{13}$ The surname of Houston is derived from the ancient barony of that name, situated within the Sheriffdom of Renfrew, which, under its former

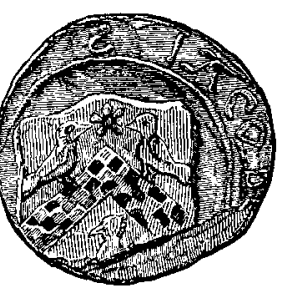
designation of Kilpeter, was acquired in the reign of Malcolm IV., by Hugo de Paduanan, ${ }^{14}$ from whom it received the name of

2 History of British Costume. Planché, p. 52.

${ }^{2}$ Caledonia, p. $63 . \quad{ }^{3}$ Dr George Mackenzie's Iives. Survey of the province of Moray, p. 33. ${ }^{3} \mathrm{M} \cdot$ 'Ure's History of Glasgow.

- "I'he Archbishoprike of Glasgow was given a young man, one Gawin Dunbar, that was the King's School Master."-Hollinshead's Scot. Chron.

7 Caledonia, p. 623. $\quad{ }^{8}$ Caledonia, p. $623 . \quad{ }^{9}$ Caledonia, p. 623.

${ }^{10}$ Gibson's Hist. of Glasgow, p. 44; constituted, according to M'Ure, 1526; received the Great Seal, August 21, 1528.

11 Spotswood's Hist. of Church Scot. $\quad{ }^{2}$ Keith's Catalogue Scot. Bis.

${ }^{13}$ On the seal a cinquefoil is plainly represonted. The sculpture presents more of the appearance of a rose. In ancient armory, however, the rose and cinquefoil were not distinet figures.

14 Regarding this person, it is only known that he was witness to the foundation eharter of the Abbey of Paisley before the end of the 12th century. 
Huston' ( Villa Hugonis), afterwards written Houston. His posterity, assuming their surname from the lands, became the Houstons of that Ilk, whose armorial insignia were, "a chevron checquie betwixt three martlets sable;"2 the addition of the check, ${ }^{3}$ as stated by Nisbet, having been adopted from their over-lords, the family of the High Stewards. It does not appear that the Subdean was immediately related to the principal family of his name. With the other figures of the coat unchanged, the rose might have been regarded as a mark of cadency, or the altered position of the martlet might have been so considered; but a mark of cadency superadded on a coat already distinguished from the original bearing would seem to indicate a more remote connection. Probably related to the Sub-dean was " Mr John Houstone (A.D. 1558), Vicar of Glasgow, the Regent in the 'Pedagogue.",

James Houston, described by M'Ure as a "learned man," acquired, like Dunbar, his education at the University of Glasgow. In 1523 he was Vicar of Eastwood, and witness to an instrument by Gavin, the Archbishop, confirming certain privileges to the Dean and Chapter of Glasgow. ${ }^{4}$ As Incumbent of the Rectory of Monkland, he appears to have been Sub-dean of Glasgow prior to the year 1527, and as such was present when doom was pronounced against Patrick Hamilton. ${ }^{5}$ In $\mathbf{1 5 3 0}$ he founded the Collegiate Church at St Thenaw's Gate (Trongate), which was dedicated to the Virgin Mary and St Anne. ${ }^{6} \mathrm{He}$ was Rector of the University of Glasgow in 1534 , in which office he continued by re-election till $1541 .^{7}$ He died in $15.50 .{ }^{8}$

Under each shield is placed a scroll, one end of which is turned upwards towards the left, and the other disposed downwards towards the right. Neither are inscribed. At each side of the shields is a rudely-formed pillar, that on the right being broken about the centre of the upper division. On the upper stone, are represented in high relief, the royal arms of Scotland, encircled with a collar of thistles, ${ }^{9}$ supported by two unicorns mounting, denuded of their

1 Orig. Par. Scot., vol. i., p. 83.

arawford's Hist, of Renfrewshire.

3 Of the families to whom this feudal addition was aceorded, Nisbet enumerates-the Houstons of Houston, the Birsbanes of Bishopton, the Shaws of Bargarran, and the Flemings of Barochan, to which I would add the Freelands of Freeland (parish of Erskine), an impression of whose ancient seal armorial, from a grant by Stewart of Kilecroy, is in the possession of $\mathrm{Mr}$ Freeland, Manchester. It exhibits a bend dexter chequé between two bears' heads and necks, couped and muzzled, and round which the inscription, " $\mathrm{S}$ * ROBERTI * FREE-

LAND *" This seal-unknown to Nisbet-does not occur in Mr Laing's printed collection.

- Note by Mr H. Laing.

- Orig. Par. Scot.

5 Spotswood's Hist. Ch. Scot., p. 63.

8 New Hist. of Glas., by J. B., Senex, \&c.

- Whether this be the collar of the Order of $\mathrm{St}$ Andrew, or an instance merely of the practice of surrounding the Scottish arms with the national emblem of the thistle, is not easily 
heads, the tails of which are disposed in a mauner not expressive of courage. The lower limbs of these figures rest on a kind of plane, projecting over the columns and figures of the inferior sculpture, probably expressible by the architectural term "plinth." The earliest authentic occurrence of the unicorn in Scotland, it may be remarked, connected with the monarehy, is on the coins of James III., where it is represented supporting the regal coat from behind. ${ }^{\text {t }}$

determined. If M'Ure's statement be correct (see Hist. Glasgow, p. 29) that the erection of the Gatehouse took place subsequent to Dunbar's resignation of the Great Seal, on the death of James V., an event which happened in the year 1542, it would argue in favour of the former. There is, however, no jewel or pendant-unless we may suppose the small escutcheon, already noticed, an early example of the oruament afterwards charged with the figure of $\mathbf{S t}$ Andrew. It is stated by the editor of "Parker's Glossary" $(p, 195)$ that the Order was revived by James $V$. in or about the year 1540, but became disused about half a century afterwards, although the collar of the Order of the Thistle or St Andrew is found surrounding the achievement of King Charles II., in the example of that monarch's aruns given by Sir Geo. Mackenzie, in his work on heraldry, published in 1680. On the 29th of May, however, in the year 1687, this order was formally restored by charter of James VII., which contains the following traditional account of its institution, probably as authentic as the portraits of his re. mote progenitors which adorn the walls of Holyrood Palace. "Quum serenissimus decessor noster, Scotorum Rex, Achaius, Ordinem Cardui, ex summo prineipe et duodecem equitibus fratribus constantem ad Salvatoris et Apostolorum suorum numerum alludens, sub protectione Andreæ Scotiæ patroni instituisset, in memoriam insignis victoriæ ejusdem $\Delta$ chaii ad versus $A$ thelstanum, Saxonum Regem, post prelium, cruentum ibidem pugnaretur, in coelis effulsit crux alba decussata, ad formam illius quæ Saneti Andreæ martyrio est sacra, quo fausto portento animati Scoti, hostes in fugam dedere."-(Parker's Glossary, p. 195.)

${ }^{1}$ Probably the earliest extant example of this figure oceurring in seulpture is that to be met with on one of the buttresses of Melrose Abbey, the arms, viz., of James IV., bearing date 1505 , to which my attention has been directed by DrJ.A. Smith. Fide that gentleman's communication, Proceed. Soc. Antiq. Scot, rol. ii., p. 171. Whether, as has been supposed, the original type of this figure be the Indian rhinoceros, or if its origin be wholly fabulous, is not distinctly known. Two kinds of unicorn are to be met with on the sculptures, and in the writings of the ancients, viz., the Bull-Unicorn, and the Horse-Unicorn. Of the former, a well-preserved example cecurs on the Nimroud obelisk in the British Museum, and a more modern instance on the Forteviot sculpture at Freeland House. The Rev. J. Campbell, author of "Travels in South Afriea," mentions that the Hottentots brought him a head with "a straight horn projecting three feet from the forehead, about ten inches above the tip of the nose." This specimen, since deposited in the museum of the London Missionary Society, Mr Campbell informs us "is considered by Naturalists" " the same that is described in Job xxxix." It is stated by Mr Willement, in his "Regal Heraldry" (p. 70), in reference to the insignia of Queen Jane Seymour, that her arms were supported on the sinister by the unicorn, a figure which, according to that author, had maintained its place in the achievement of the Dukes of Somerset; and again of the arms of this Queen, in another example, that the animal occurs argent royally crouned. The title of Somerset appears to have been held by the Beaufort family from about the year 1396 to 1471, when Edmund Beaufort, the last Duke of that surname was beheaded. The title of Duke of Somerset would appear 
Under the royal arms in this sculpture appears a diminutire escutcheon, which, in the view of the stone, obtainable only through the framework of a window in an old staircase, seems to contain the letter I and figure 5, obviously referring to the style of the reigning monarch. The upper portion of the stone, which contains the mantling, and underneath the remains of the national crest, displays the imperial helmet surmounted with the diadem, bears evidence of the dilapidation produced by time. The lion composing the principal figure of the charge, it will be observed, is represented with full face ${ }^{1}$-rampant gardant, as expressed in heraldry. This coat has been idly supposed the insignia of James V., as a dignitary of the cathedral. There is evidence to show that this monarch's immediate predecessor; James IV., held office as a canon of the Cathedral Church of Glasgow, ${ }^{2}$ and the former, we read, was bailiff or steward of Melrose, under the Abbot, ${ }^{3}$ but had not, that 1 can discover, any connection with the See of Glasgow, unless in so far as his benefactions to the Blackfriars or Dominican convent may be held as qualifying the negation.

The Episcopal Palace, or Castle, stood on the vacant space in front of the present Infirmary, immediately south-west of the cathedral; but when, or b5 whom founded, does not appear. The great tower, which formed the principal portion of the building, was erected by Bishop Cameron about the year $1430,{ }^{4}$ and nearly a century later appears to have been augmented by Archbishop Beaton. ${ }^{5}$ On this tower, we are informed by M'Ure, the historian of Glasgow, "his arms are yet to be seen (1736) with an escutcheon, ensigned with his crosier [pastoral staff] behind the shield, surmounted of a salmon fish, the badge of the Episcopal See, and his name above in great Saxon capital letters." This I take to be the sculpture represented by Plate VIII., the re"production of an original pen-and-ink sketch exeeuted by "John Hopkirke" in "1752," which, with the view of the "Gatehouse," by the same individual, given in Plate IX., were, in 1846, in the possession of the late Mr James M'Ewan of Glasgow, to whose kindness, in permitting me to copy them, I am enabled to present them in their present form. These were marked, in the

afterwards, with some interruption, to have been conferred on Edward Seymour, who died in 1551. James I. of Scotland married Joan Beaufort, daughter of $J_{0 h n}$, Earl of Somerset; but whether the families of Beaufort and Seymour were in anywise conmected I am unable to say. If they were, it suggests a possible explanation of the oceurrence of this figure in the Royal Insigna of Scotiand.

1 The royal beast in this position, Nisbet terms a Lion-Leopardee. "Ancient and Modern use of Armories," Edin. 1718, p. 163.

2 Orig. Par. Scot. vol. i., p. 11.

- Charter in Pub. Arcb. Edin., cited by Robertson, Hist. Scot. Edit. 1787, p. 8.

- Denholin states positively $1426 . \quad$ Denholm's Hist. Glasgow, 1804, p. 127. 
handwriting of the artist, "Bishop's Palace," and numbered respectively 3 and 5 ; apparently two of a series of sketches perhaps originally intended to illustrate some topographical publication connected with the city of Glasgow. The term "surmounted," occurring in the preceding extract from M'Ure, is probably a typographical error. Nisbet gives the arms of this prelate, supported " at the sides of the shield" by "two salmons with rings in their mouths." The characters of the inscription contained on this seulpture appear to have been of the form generally expressed by the term Longobardic. The first word is in the wrong case. The omission of the letter $\mathrm{H}$ is not unusual. I am not aware that these sketches have ever been engraved. Of the palace, the entire structure was built of hewn stone, and inclosed with an embattled wall fifteen feet high, ${ }^{1}$ ornamented at certain points with the arms of Archbishop Beaton, ${ }^{2}$ who built that addition about $1510,{ }^{3}$ previous to which the castle was defended by a fosse with a drawbridge and portcullis. ${ }^{4}$ [See Plate $\mathrm{X}$., which gives a view of the palace copied from Slezer's View of Glasgow, published in 1693 . It also shows the Tower and other parts of Glasgow Cathedral which have since been removed. Plate XI. shows the relations of the different parts of the Bishop's palace to one another, and to the Cathedral, in a carefully prepared ground plan.] The wall, which was of an irregular form, extended on the west from within some fifty yards of the head of Kirk Street, along the centre of Castle Street, to a point on a line with the front of the Infirmary, where stood a circular tower, the remains of which, with the steps of the sunk portion (ten in number), were removed in $1853 .^{5}$ The northern inclosure was formed by two walls extending from the extremities of the east and west walls; that from the eastern in a north-westerly, and that from the western in a north-easterly direction, forming a right angle at their junction. A cross wall, proceeding south-eastward from the termination of the western inclosure, united with the south-east wall, nearly opposite the head of Kirk Street, where stood a high tower, quadrangular and embattled, and surmounted at each gable by a flight of steps, from the outer angles of which projected a species of turret. In front of the angle formed by the junction of the west and south-west walls was constructed a bastion. At the extremity of the south-east wall (which formed a slight angle inwards at the centre), fronting the south-east, and uniting with the east wall immediately southward of the consistorial house formerly attached to the cathedral, was situated the

1 Memoranda by Robert Reid, Esq.

- Anoient and Modern Use of Armories. Nisbet, p. 81.

TChronicles of St Mungo, p. 53 . Notes by Thomas Jobnston, Esq. F.S.A. Scot.

Ibid. 
main entrance or Gatehouse. ${ }^{1}$ This imposing structure, the gables of which terminated at the roof in a flight of crow-steps, was of a square form, and displayed an embattled front, flanked by two circular towers, ${ }^{2}$ each of which contained an upright oblong compartment. Into one of these recesses was placed the sculpture represented in Plate VII. This portion of the edifice was erected during the episcopate of Archbishop Dunbar, between the years 1524 and 1547. Its construction has hitherto been attributed exclusively to that prelate, ${ }^{3}$ though, if for this statement there be no higher authority than the occurrence of the Archbishop's coat armorial, the presence of the insignia of the Sub-dean, with which it is conjoined, must be held as equally potent in supporting the claim of the latier to a share in its erection.

In 1755 the magistrates of Glasgow, in the exercise of a doubtful right, granted permission to remore certain portions of the castle structure, to aid in the erection of the Saracen's Head Inn ; ${ }^{4}$ about which time the sculptures exhibited in plate VII., having passed into the hands of a citizen named Charles Salkirk, ${ }^{5}$ were subsequently built into the wall of the tenement in which they are now contained. To this circumstance the date and initial letters ${ }^{6}$ placed on a small tablet, over the upper stone, plainly refer, while they may be held as evidence of the fact.

Extending in front of the castie wall, on the south-east, was the ancient avenue leading to the cathedral. This road, which presented appearauces of great age, was constructed of small pieces of trap rock firmly embedded in some substance as a kind of mortar, ${ }^{7}$ which had acquired the consistency of solid rock. Up to the period of its removal it was not known to have undergone repair, whence probably arose the popular notion referring its formation to the period of Roman occupation. It is now generally supposed to have been the work of the first Archbishop Beaton, who, as already stated, inclosed the palace at the beginning of the sixteenth century.

\footnotetext{
1 Denholm, the author of a History of Glasgow, appears to have confounded the ruins of the "Gatehouse" with the remains of the Castle Gate, one of the city ports.

2 The parapets of this edifice (vide Plate IX.) were supported by a double row of dieshaped-corbels, the under tier of which, according to the prevailing custom, was machicolated for the purposes of defence.

3 If there be any eontemporary document to anthenticate this statement, it is not within my knowledge. I should think the circumstance could scarcely have escaped the research of the author of "Origines Parochiales Scotice," who has recorded the arehitectural achievements of others of St Mungo's hierarchy.

- Private Memoranda by Robert Reid, Esq.

- Memoranda, Mr James Bogle, Writer.

C. S. 1760.
}

Private Memoranda by Robert Reid, Esq. 
Notice of the "Bishop's Garden" is found about the year 1268, but no men. 'tion of the castle till A.D. 1290, and then only incidental. ${ }^{1}$ In 1300 the Castle of Glasgow was placed under an English garrison, for the purpose, among others, of maintaining the supremacy of Anthony Bec, an obnoxious ecclesiastic, thrust into the see of Glasgow by Edward I. ${ }^{2}$ Subsequently to this, for the period of two centuries, I have met with no farther notice of this structure, till, in 1517, when judgment in an action, raised at the instance of "ane maist reverend Fader in God, James Archbishop of Glasgow," is recorded against John Mure of Caldwell," "for the wrangwis and violent ejection and furthputting of his servands out of his Castell and Palice of Glasgow, and taking the samyn fra them, the $x x$ day of Februar, the yer of God $\mathrm{JnV}^{\mathrm{n}} \mathrm{c}$ and $\mathrm{XV}$ zers," and for the "wrangwis destructioun of his said castell and place, breking down of the saymin with artalzary." "The quhilks. castell" "was spulzeit" " be the said Johnne Mure" " and his complices; Lyk as was clerly previt befor the" "Lordis of Counsale," who "ordannis lettres to be direct to compell and destrenzie the said Johnne Mure, his lands and guds tharfor." In 1517, the Castle of Glasgow was invested by John Earl of Lennox, who had joined issue with Hume and the Earl of Arran, in defying the power of the Regent, John Duke of Albany, on which occasion it was recovered by the latter with inconsiderable loss, retribution falling on a French gunner, a deserter, who had aided in its defence. ${ }^{4}$ Between the years 1543 and 1545 it was fortified by Mathew Earl of Lennox, to resist the forces of the Regent Arran, raised at the instigation of Cardinal Beaton. ${ }^{5}$ For ten days it appears to have been "battered" with "brass guns," when the garrison surrendered "upon quarter and indemnity," but were put to death. In 1553 " the inner flower-garden beside the palace," was the scene of an interview between the Archbishop and "Andrew Hamyltoun of Cochnoch, Provost, and the whole Council," where the former, "engaged in conversation with several Canons of the Chapter," was presented with "a schedule of paper," containing "the names of certain of the most worthy and substantial men of the city, from whom the Archbishop selected the bailies for the following year." ${ }^{\prime \prime}$ Pre... vions to the general outburst in 1560, Archbishop Beaton summoned to the defence of the castle the nobility and barons of Clydesdale, who adhered to

1 Reg. Glas. cited at p. 177. Orig. Par. Scot.

2 Stuart's Views and Notices of Glasgor in former Times. This event probably took place in 1301. In $1300 \mathrm{Bec}$ appears to have been a prelate of the See of Durham.

${ }^{3}$ Books of Council, vol. xxx., fol. 219, cited by Hamilton. Descrip. of Lanark, Append.

* Buchanan's History, edit. 1752, p. 137 ; Drummond's Hist. p. 251.

Buchanan's Histcry, edit. 1752, n. $193 . \quad$ Orig. Par. Scot., p. 13. 
the old faith,' aided by whom, with a party of French soldiers, he succeeded in dislodging the emissaries of the Duke of Chatelherault, who had taken forcible possession. On the flight of Beaton at the Reformation, the Castle of Glasgow was again seized by the Duke," who was eventually compelled to deliver it up to the Earl of Lennox. ${ }^{3}$ It is recorded of this prelate, the last of the Romish hierarchy who held the See of Glasgow, that having plundered the See of its golden ornaments, and vestments, he despoiled the cathedral archives of all its valuable records, retiring with them into France. Some of these, through the well-directed efforts of the Abbé M'Pherson, a member of the Scottish College at Paris, within which they had been deposited, were recovered at the French Revolution.4 Beaton, who, after his deprivation, had served in the capacity of Scottish ambassador to the Court of France, was restored by act of Parliament to the temporalities of the See of Glasgow, which, without its immunities, he enjoyed till his death in 1603. In 1571, says Buchanan, "The Hamiltonians" went to Glasgow, resolving to demolish the castle of the Archbishop there, that it might not be a receptacle to the Farl of Lennox, then returned out of England. The castle at this time appears to have been garrisoned by "a few raw soldiers (twenty-four in number) unprovided of necessaries," and the governor absent. "Hearing, however," of "a design speedily to relieve the castle," "the Hamiltonians" "raised their siege, and in great fear packed away." The Bishop's palace was restored in 1611, during the episcopate of Archbishop Spotswood. ${ }^{6}$ It is stated by James Barns, ${ }^{7}$ a Glasgow bailie, and chronicler of the middle of the seventeenth century, whose "Memoirs," in MS. ${ }^{8}$ are preserved in the Advocates" Library, that in August 1654, for four days, were detained prisoners in the Castle of Glasgow, preparatory to their being sent to Edinburgh, Colonel Robert Montgomery, son of the Earl of Eglinton, and fourteen men apprehended with him at Kilmarnock. "The Castle of Glasgow" is noticed by Hamilton of Wishaw, in his

1 M'Ure's Hist. of Glasgow, p. 38.

2 Orig. Par. Seot., p. 7.

3 The lordship of the Archbishop's Castle, according to Brown, eame to the family of Lennox, in virtue of a transaction with a priest of the name of Montgomery (preferred to the Arehbishopric, through the agency of the Duke de Aubigne), who for the annual payment of one thousand pounds Scots, some horse-corn, and poultry, transferred to his patrun, his heirs and successors, the whole revenues belonging to the See. Hist. Glasgow, p. 36.

4 The aneient Chartulary, in two volumes, and other valuable MSS., since printed for the Bannatyne and Maitland Chubs.

5 Bue. Hist. of Scot., p. $405 . \quad$ Caledonia, p.629.

7 The name of this person was Barns-Burns is a mistake of the transcriber.-Sencx.

- A transcript. Since edited and printed by Mr Maidment, advocate.

- Memoranda by Robert Reid, Esq. 
"Description of the Sheriffdom of Lanark," as "the ancient seat of the Archbishop of this sea built of polisht stone, and yet in good condition:" by Slezer, the unfortunate Dutch captain of artillery, as "fenced with an exceeding high wall of hewn stone," looking "down upon the city;"' by Rae in 1661-cited by the author of the "Chronicles of St Mungo"-as "a goodly building near the church," "still preserved;" and in Morer's account of Scotland (1689), as "without doubt a very magnificent structure, but now in ruins, and" "no more left in repair than what was the ancient prison, and is at this time a mean dwelling."1 (Probably the square tower erected by Beaton, and contiguous building.) The date 1689 obviously points to the tumults consequent on the abolition of Episcopacy, during which the castle appears to have been partially demolished. About this time it became the property of the Crown ; and in 1715 was used as a temporary prison for upwards of three hundred Highlanders, taken during the rebellion. ${ }^{2}$ At length, neglected and in ruins, the whole structure, with the castleyard and garden, were in 1791 granted by the king for the purpose of erecting an infirmary.

"In ancient times," says M'Ure, "all or most of the city was built near the Episcopal Palace, or Bishop's Castle." This consisted of the "Kirkgate," the "High Street," the "Drygate, and "Rotten Row," in which, "near the Castle," was held "the twenty day of Yuill, or St Mungo's Fair. West of the quadrangular wall-tower constructed by Archbishop Beaton, "near the Bishop's castle and palace," stood the "Hospital of St Nicholas or Almshouse," said to have been founded by " Bishop Andrew Muirhead, 1455-1473."3

During operations for removing the mound in front of the Infirmary, so recently as the year $\mathbf{1 8 5 3}$, traces of the ancient ditch which surrounded the castle were visible in a dark-coloured incrustation, evidently formed by the feculent deposit usually found at the bottom of stagnant water. ${ }^{4}$ At the same time were found the ancient drawbridge, consisting of twelve beams of oak, pegged together, of the length of 15 feet ; at the point formerly oceupied by the Gatehouse, four oak piles, 4 feet in length, and 15 inches broad either way; several cannon balls, weighing each 36 lbs.; a few silver coins ; remains of an ash-pit containing several lambs' skulls, and some oyster shells; the stone used in fixing the gallows during the execution of criminals within the castle-yard; and a portion of a human cranium. ${ }^{5}$ Some remains of the bastion constructed by Archbishop Beaton, discovered near the head of Kirk Street, had become so consoli-

1 Defoe, writing in 1727 , calls it " a ruinous castle," and repeats the remark of Slezer, alluding to its enclosure by "an exceeding high wall."

2 Stuart's Views, \&c.

s Orig. Par, Scot.

4 Notes by Thomas Johnston, Esq., F.S.A. Scot.

Ibid. 
dated as to require the process of blasting to effect its removal. ${ }^{1}$ Fragments of the palace, and some steps taken from the circular staircase of the great tower, the latter having been converted into flat tombstones, are still distinguishable within the cathedral yard.

In the Burgh Records of Glasgow, presented by the late Dr Smith of Crutherland to the Maitland Club, are inserted (without reference to any portion of that work) two views of the Bishop's Palace of Glasgow, one of which, exhibiting the remaining portions of the structure in a ruined state, purports to have been taken from the painting stated by Brown in his History ${ }^{2}$ to have been executed before the removal of the palace in 1792. I am, however, inclined to doubt that any such painting was executed immediately preceding the removal of the castle ruin, the same view having been printed for sale by the Messrs Foulis in 1757. In the Glasgow Journal of 21st February 1757 occurs the following advertisement:- " On Wednesday next will be published, and sold by R. and A. Foulis, a View of the Cathedral of Glasgow from the north. A view of the same, and of the Ruins of the Old Castle from the west."3 The other sketch, presenting not strictly a view of the "Episcopal Palace" (a very minute part of which only is exhibited), but of the wall tower erected by Beaton, southeastern enclosure, and remains of the Gatehouse, is merely a reduced copy of a print belonging to "The Antiquities of Great Britain," engraved in 1783 by W. Byrne and T. Medland, from a drawing by Thomas Hearne, the figures of which are engraved by $F$. Bartolozzi,-information for which I am indebted to one of the secretaries of this Society, Dr J. A. Smith, whose politeness in transmitting, for my inspection, a copy of the original engraving, it gives me pleasure to acknowledge. Through the kindness of this gentleman, 1 am farther enabled to state, on the authority of Mr Laing, F.S.A. Scot., that a view of Glasgow Cathedral, exhibiting a portion of the castle ruins, engraved in 1780 by W. Angus, from a painting by P. Sandby, R.A., occurs in a book entitled "The Virtuosi's Museum," Lundon, 1778-80.

Of the remains of Archbishop Dunbar, discovered in 1855, during the repairs executed within the choir of the cathedral, some account may here be not without interest. The sarcophagus of this prelate was found about two feet from the surface of the pavement, in one of the hollows formed by the arches of the crypt which supports the basement of the choir, and between two pillars immediately

1 Notes by Thomas Jolnnston, Esq., F.S.A. Scot.

3 Hist. Glasgow, 1795, p. 64 ; see also Chronicles of St Mungo, p. 54.

${ }^{3}$ Memoranda by Robert Reid, Esq. 
south of the present palpit, which stands on the spot formerly occupied by the high altar. It was disposed in the usual manner from west to east, and consisted of sundry pieces of dressed freestone, some of which, laid flat, formed the bottom of the coffin,--others, set up on edge, composed the ends and sides. Over these, in the form of cover, was placed a sheet of lead about one-eighth of an inch in thickness, and above this covering another of dressed flags, corresponding to those already described, the whole being cemented together with mortar. - The sarcophagus contained an entire skeleton in a state of perfect preservation. ${ }^{1}$ Within it were found a border and fringe of rich gold tinsel, on which appeared a figure resembling a quatrefoil, which, I was informed, on being exposed to the atmosphere fell to powder; and, covering a portion of the skeleton, the remains of a fringed silk vestment, presenting a brownish appearance, portions of which, with a cast from the skull found within the cist, I present to the Museum of the Society. Adhering to other parts of the skeleton were pieces of waxed cerecloth, anciently used in the process of embalming. The length of the cofflin inside was 6 feet 2 inches. With reference to the question of identity, $I$ have elsewhere stated, on the authority of Keith, that Dunbar's remains were deposited in a tomb erected by himself "within the chancel of his cathedral." Keeping in view this fact in relation to another fact, the inhumation, viz., of the Protestant Archbishop Boyd in 1578, of whom Spotswood records that he "was solemnly buried in the quire of the cathedral" "in the sepulchre of Mr Gawan Dumbar," the matter will presently become very distinct. This tomb was ransacked at the commencement of the present century (about 1804), by an adventurous young man, afterwards well known in Glasgow, who, with some of his companions, under night, effected an entrance into the interior of the cathedral, the object of attraction being the sarcophagus of Archbishop Boyd, disclosed on the previous day during the alterations then in progress. The following information is given on the authority of a gentleman conversant with the leading facts, ${ }^{3}$ whose verbal statements some years since 1 committed to paper. The foundations of the tomb then discovered and removed, measured "some 10 to 13 feet square inside," within the southern wall of which, " not far from the surface," was placed the coffin of Archbishop Boyd, bearing "his arms and initials ;" and over against the opposite foundation, " nearly on a line with the centre of the two pillars," "on the left hand side of the pulpit (rather

1 Theso remains, having been omitted to be replaced in the cist before it was finally covered up, were subsequently deposited in a hole dug for their reception at the fuot of the steps leading from the great western entrance into the cathedral.

\& Hist. Church Scot., p. 303.

${ }^{3}$ Mr James Bogle, writer, lately deceased. 
nearer the cathedral wall)," another "coffin of parement stones," which, according to my information, was left undisturbed. "In the empty space between the two coffins some loose bones were dug up; but no other coffin, or anything in the shape of a separate internent. One or two silver coins were found by the workmen." It will thus be seen that the principal facts of both discoveries are reciprocally verified. The position of Koyd's coffin from which, on the previous occasion, the skull had been abstracted, having, in relation to the latter, been sufficiently ascertained. An aged correspondent, still alive, in allusion to this nocturnal visit, thus writes: "They opened the grave of the Archbishop [Boyd], which, having examined, they found therein various interesting relics. These they replaced in situ, and then closed the grave in pretty much the same way as it stood before their examination took place." From the confessions in after life, however, of the principal actor to his intimate friends, it would seem more than doubtful whether the relics referred to were "replaced in situ," or replaced at all ; all the facts that have been allowed to transpire rather pointing to an opposite conclusion. It is affirmed that this individual also visited the tomb of Bishop Wischard, in the crypt of the cathedral, performing certain acts, "which it is not for his honour that we should remember, and which are not now distinctly known."

\section{January 19, 1857.}

\section{ARCHIBALD T. BOYLE, Esa., Vice-President, in the Chair.}

The following Gentlemen were elected Fellows of the Society :-

Lieut.-Col. Peter Barclay, H.E.I.C.S.

George Patrrson, of Castle Huntly, Esq., Adrocate.

Charles Stethen Lescie, younger of Balquhain, Esq.

There was exhibited-

A Portrait of Alexander Brodie of Brodie, Lord Lyon King-atArms (1728-1732), in his Robes of Office. From the Collection at Dunvegan Castle. By JoHN C. Brodre, Esq., W.S.; voL. II. PART III. 
And a Manuscript in Vellum of the Jewish Law, within a case. By Mrs Gow, Albany Street.

The Donations to the Museum and Library were as follows:-

Twenty-one Rupees and other Indian Coins, some of them old and uncommon. By Allan Scotr, Esq., H.E.I.C.S., Corr. Mem. S.A. Scot.

Various Egyptian Antiquities; being a portion of a valuable Collection made in Egypt, by A. H. Rhind, Esq., and intended for presentation to the Society of Antiquaries of Scotland. By A. Henry Rhind, Esq., F.S.A. Scot.

Plaster Casts of a Stone Cross, with Runic inscription, from Braddan churchyard : also of a

Stone Cup or Patera, found at Santon, Isle of Man : and of a

Stone Celt or Axe Head, of a peculiar hatchet-like shape, found at the Currach, in the Isle of Man. By the Rev. J. C. CumMING, M.A., Lichfield.

Memoir written during a Survey of the Watling Street, from the Tees to the Scotch Border, in 1850-51, made by direction of the Duke of Northumberland, by Henry Maclauchlan. 8vo, pp. 42, with Folio Atlas of Plates. London, 1852 ; and the

Archæological Journal, June, 1856. 8vo. No. 50. By the ARCH AOLOGICAL Institute of Great Britain and Ireland.

Bronze Medal struck in Commemoration of the Centenary oF the Birthday of Roscoe, Liverfool, March vili. mdcccliti. Obverse, Head of Roscoe, and below, MaYer - Liverpool Direxit; the

Inventorium Sepulchrale; an account of some Antiquities dug up in the county of Kent from 1757 to 1773 , by the Rev. Bryan Faussett. Edited by C. Roach Smith. 4to. London, 1856; the

Catalogue of the Fejérvary Ivories in the Museum of Joseph Mayer, Esq., Liverpool, preceded by an Essay on Antique Ivories, by F. Pulsaky. 8vo, pp. 55. Liverpool, 1856; and the 
History of the Art of Pottery in Liverpool, by Joseph Mayer, Esq. 8vo, pp. 37. Liverpool, 1855. By Josepir Mayer, Esq., F.S.A., Liverpool.

The following Communications were read :- 
VOL. II. PLATE VII.

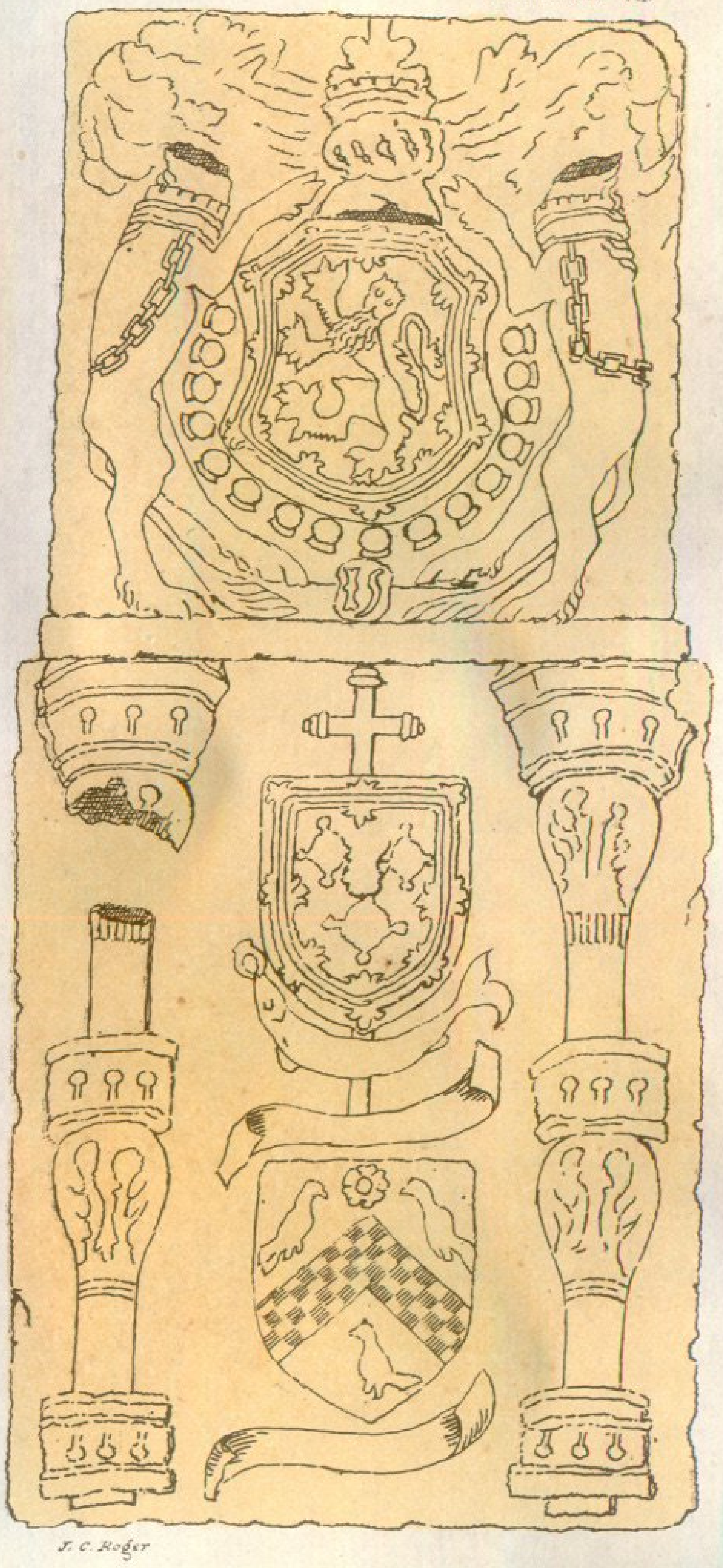

Proceedings of the Society of Antiquaries of Scotland. 


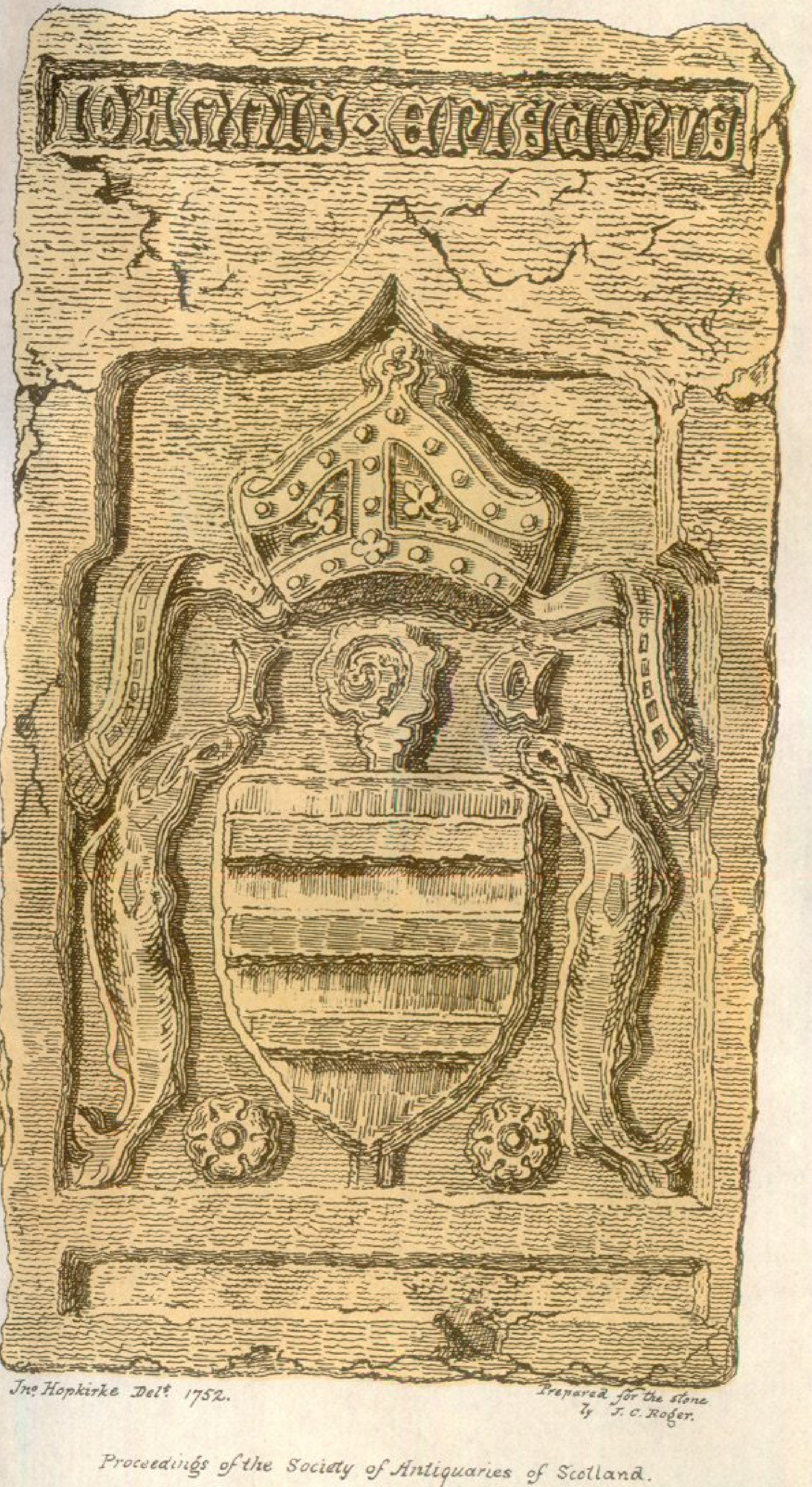




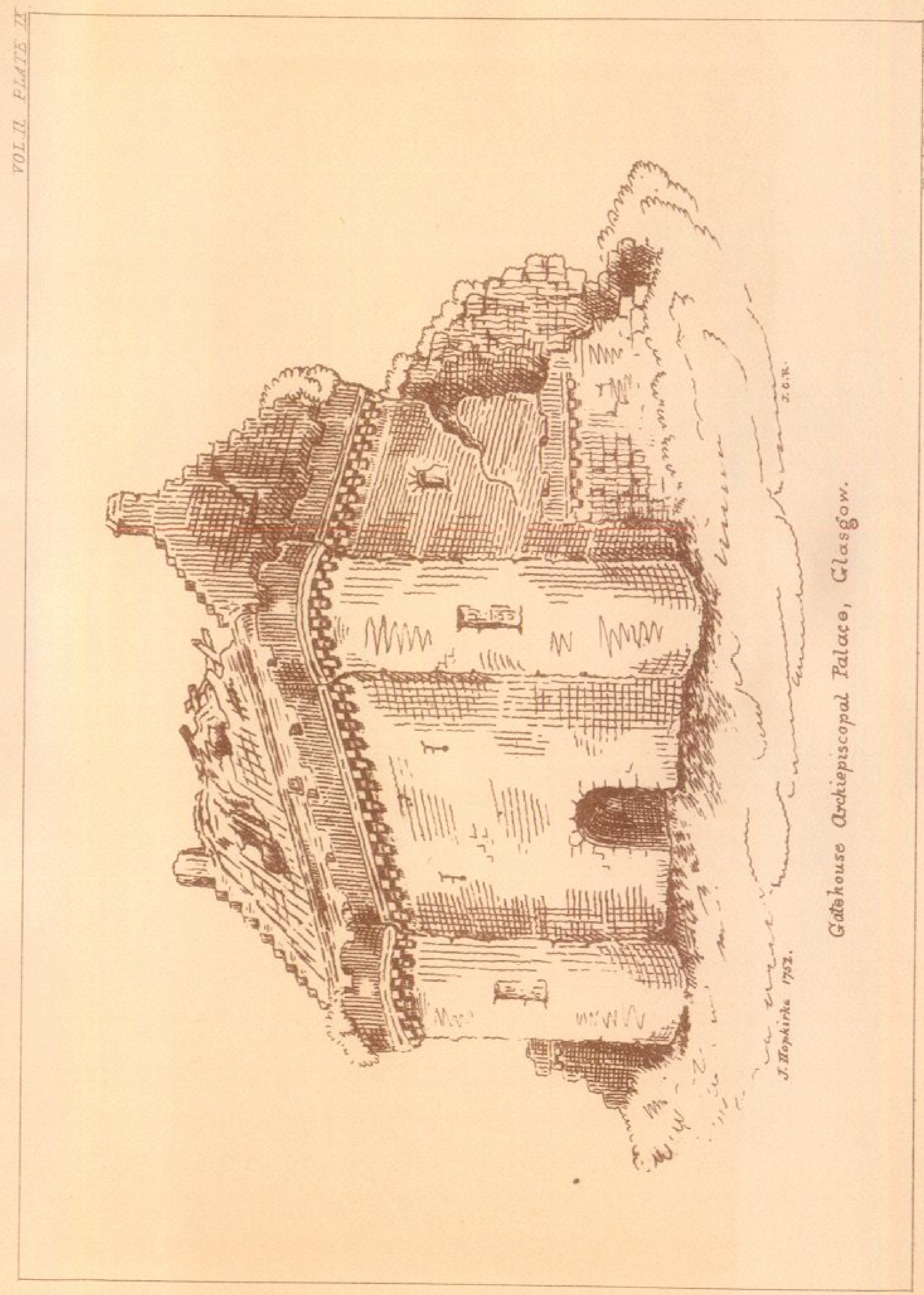




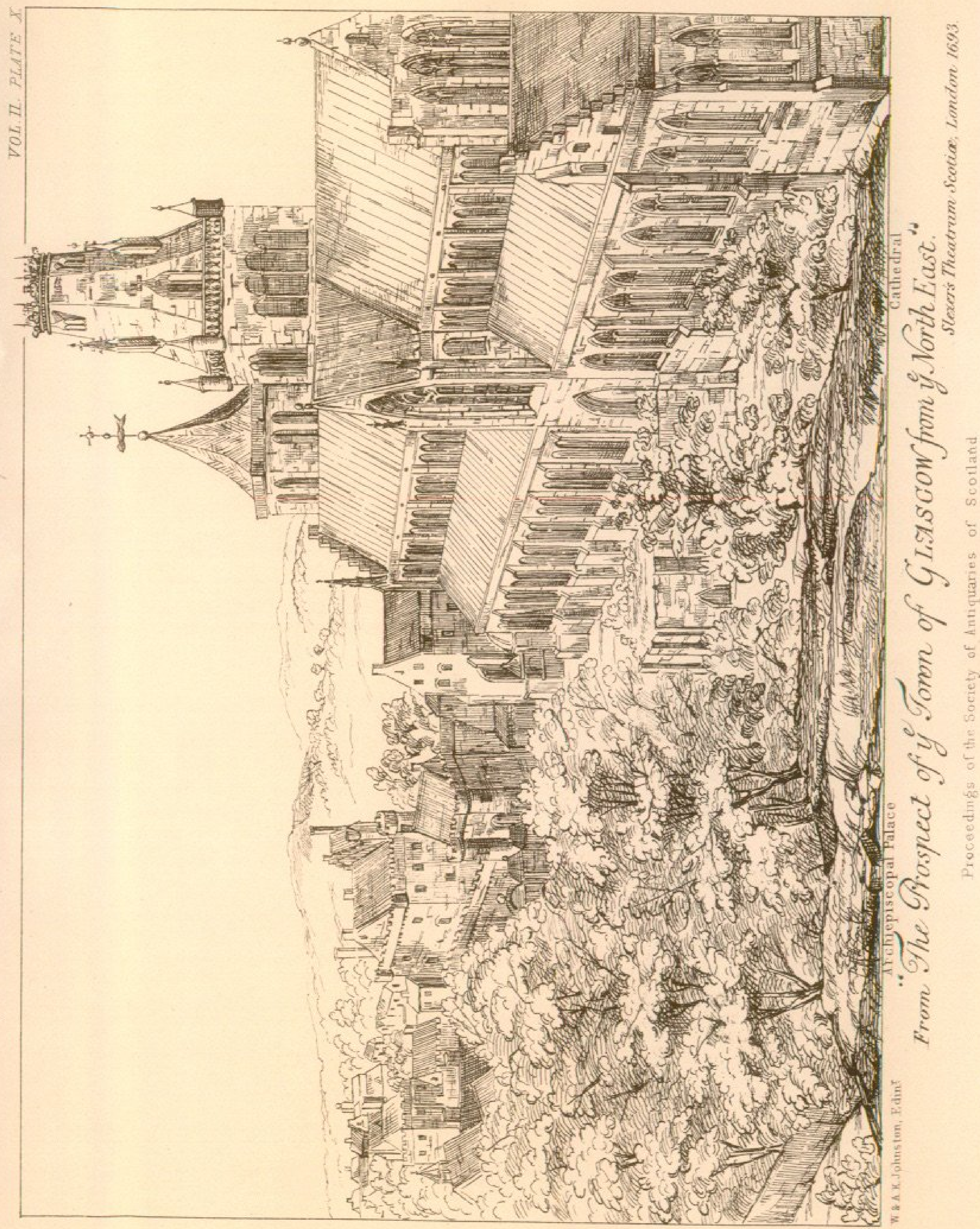




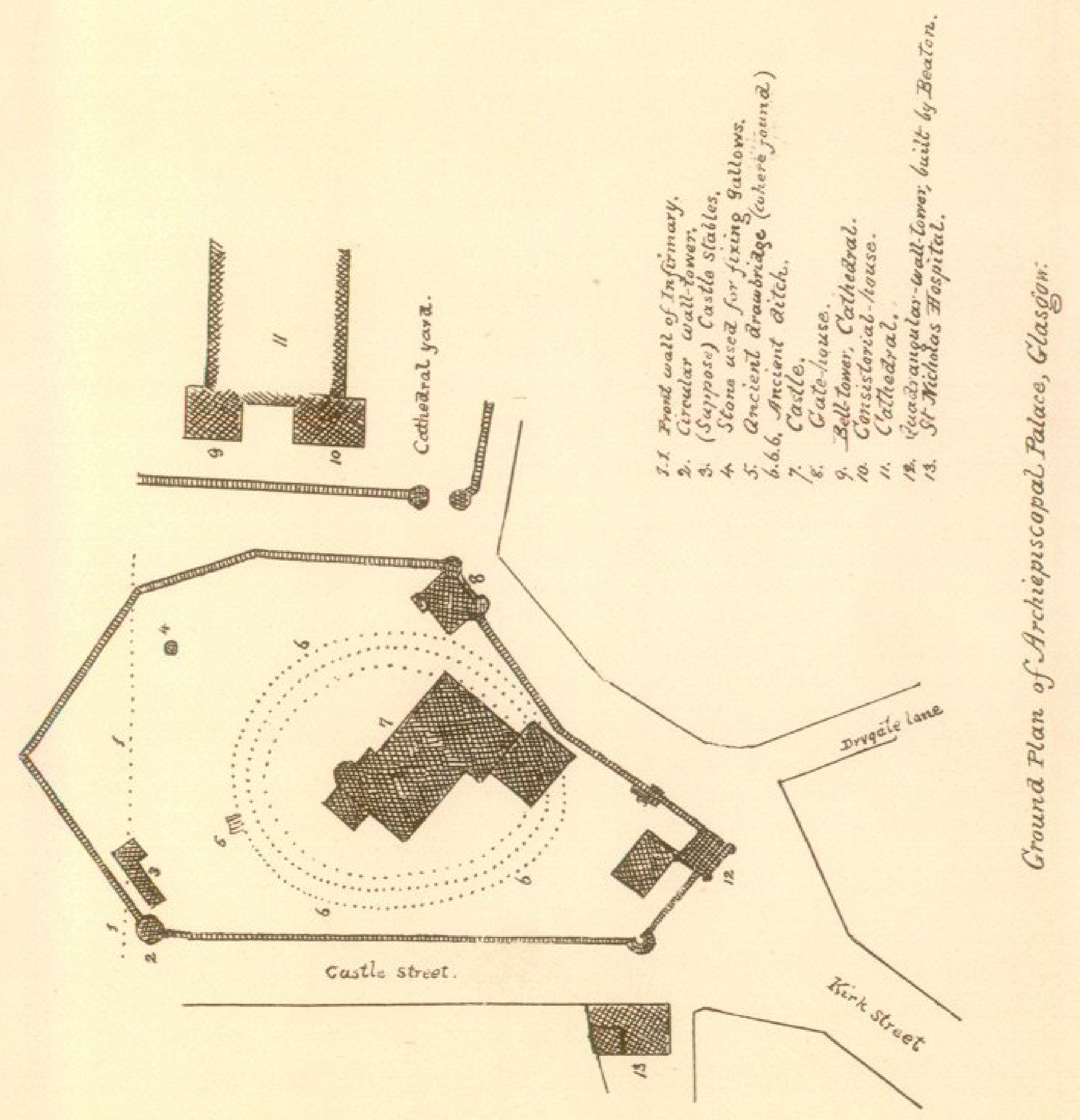

